\title{
EFFECT OF PLANTING DATES ON INFESTATIONS WITH CERTAIN PESTS AND YIELD PARAMETERES OF SQUASH PLANTS
}

\author{
MONA A. MOHAMED
}

Plant Protection Research Institute, ARC, Dokki, Giza, 12618 Egypt

(Manuscript received 20 March 2011)

\begin{abstract}
The effect of four planting dates of squash seeds (March, $15^{\text {th }}$, April, $1^{\text {st }}$, April, $15^{\text {th }}$ and May, $1^{\text {st }}$ ) on levels of infestation with three pests, aphid, Aphis gossypii Glover, whitefly, Bemisia tabaci (Genn.) and thrips, Thrips tabaci Lind. and on yield of this plant, were studied during two successive seasons (2009 and 2010). The degree of infestation by these pests increased significantly by delaying planting date, as squash plants cultivated in the earliest planting date (March, $15^{\text {th }}$ ) were attacked by the fewest numbers with highest weight of squash fruits, while the plants of the latest planting date (May, $1^{\text {st }}$ ) were more liable to insects infestation with lowest weight of squash fruits. The results showed that, the mean rate of infestation with $A$. gossypii were $(2.82,4.07,17.27$ and 30.78 individuals/leaf) during 2009 season, (0.28, 3.35, 9.04 and 13.27 individuals/leaf) during 2010 season for the four dates, respectively. So, the earliest date (March, $15^{\text {th }}$ ) led to plants harboured the lowest population of $A$. gossypii (2.82 and 0.28 individuals/leaf in the two seasons, respectively), also, the highest weight of squash fruits $(9.39$ and $10.89 \mathrm{~kg} / \mathrm{plot}$ in the two seasons, respectively) was obtained. The same trend were recorded for the populations of $B$. tabaci and $T$. tabaci on squash plants during the two seasons. Therefore, it was concluded that, the plant date was effective on the rate of infestation with pests and yield of squash plants and can be avoided by planting it as early as March, $15^{\text {th }}$.
\end{abstract}

\section{INTRODUCTION}

Cucurbits represent an important part of vegetable production and are considered very important in agricultural crops in Egypt. They are cultivated in wide areas either old lands or newly reclaimed lands. The high production of cucurbit vegetables especially squash (Cucurbita pepo L.) is of prime important aspect for local consumption and for export purposes. This crop is infested by many pests, which are causing a considerable damage in either quantity or quality. They have established attacking by many important insect pests such as aphid, Aphis gossypii Glover, whitefly, Bemisia tabaci (Genn.) and thrips, Thrips tabaci Lind. The nymphal and adult stages of these pests feed on phloem sap and excrete honeydew that hamper photosynthesis and render fruits unmarketable, and they are efficient vectors of plant 
viruses Rizk and Ahmed (1981), Shetgar et. al. (1994), Jarosik et. al. (1997), Booij (2003), Efil (2003), Sahu et. al. (2005), Emam et. al. (2006) and Anuj Bhatnagar (2007).

The aim of this study is to avoid those injurious pests infesting squash without applying any chemical pesticides, which have some bad side effects on green pods and seeds, as well.

\section{MATERIALS AND METHODS}

This study was conducted in Toukh district, Qualubia Governorate during the summer plantation seasons (2009 and 2010). Seeds of squash plants, Cucurbita pepo Fam. Cucurbitaceae (variety Eskandrany) were sown in four different planting dates at 15 days intervals, March $15^{\text {th }}$, April, $1^{\text {st }}$, April, $15^{\text {th }}$ and May, $1^{\text {st }}$. Normal agricultural practices were followed without insecticides treatments.

The experimental area about $480 \mathrm{~m}^{2}$ was divided into 16 plots (each plots was $30 \mathrm{~m}^{2}$ ). The experimental plots were laid out in a randomized complete block design and each planting date was represented by four plots. Sampling of squash plants started 15 days after sowing and were taken weekly until the end of experiment. In each sampling date, 25 leaves were picked randomly per plot, and the collected samples were kept in tight closed paper bags and transferred to the laboratory for investigation by stereomicroscope to count the number of $A$. gossypii nymphs and adults/ leaf, T. tabaci nymphs and adults/leaf and $B$. tabaci nymphs/inch ${ }^{2}$. Resulted squash fruits of each planting date were collected and weighted to estimate the final yields.

Statistical treatments of data were analyzed according to Fisher (1950).

\section{RESULTS AND DISCUSSION}

Data in Tables (1 to 4) show the effect of four different sowing dates on the infestation of squash leaves by main leaf pests during two seasons of 2009 and 2010 and on yield:

\section{1) Aphis gossypii (nymphs and adults):}

Results in Table (1) revealed that the population density of $A$. gossypii (nymphs and adults) on squash plants differed significantly according to the sowing date during the two successive seasons 2009 and 2010. In the first season, the population density of $A$. gossypii individuals increased by delaying planting date. The squash plants were sown in the earliest planting date (March, $15^{\text {th }}$ ) infested significantly by the lowest mean number of $A$. gossypii ( 2.82 individuals/leaf). On the contrary, the plants of the last planting date (May, $1^{\text {st }}$ ) harboured highest numbers of A. gossypii (30.78 individuals/leaf). 
Table 1. Mean number of Aphis gossypii Glover individuals/leaf on squash plants in different planting dates during the summer plantation seasons of 2009 and 2010.

\begin{tabular}{|c|c|c|c|c||c|c|c|c|}
\hline \multirow{2}{*}{$\begin{array}{c}\text { Sampling } \\
\text { schedule }\end{array}$} & \multicolumn{9}{|c|}{2009} & \multicolumn{3}{c|}{2010} \\
\cline { 2 - 9 } & $\begin{array}{c}\text { March, } \\
15^{\text {th }}\end{array}$ & $\begin{array}{c}\text { April, } \\
1^{\text {st }}\end{array}$ & $\begin{array}{c}\text { April, } \\
15^{\text {th }}\end{array}$ & $\begin{array}{c}\text { May, } \\
1^{\text {st }}\end{array}$ & $\begin{array}{c}\text { March, } \\
15^{\text {th }}\end{array}$ & $\begin{array}{c}\text { April, } \\
1^{\text {st }}\end{array}$ & $\begin{array}{c}\text { April, } \\
15^{\text {th }}\end{array}$ & $\begin{array}{c}\text { May, } \\
1^{\text {st }}\end{array}$ \\
\hline April, 1 & 0.00 & - & - & - & 0.00 & - & - & - \\
\hline 8 & 0.08 & - & - & - & 0.05 & - & - & - \\
\hline 15 & 0.17 & 0.00 & - & - & 0.08 & 0.00 & - & - \\
\hline 22 & 0.44 & 0.09 & - & - & 0.20 & 0.07 & - & - \\
\hline 29 & 0.96 & 0.22 & 0.09 & - & 0.33 & 0.20 & 0.04 & - \\
\hline May, 6 & 1.67 & 0.95 & 0.20 & - & 0.29 & 0.91 & 0.12 & - \\
\hline 13 & 5.33 & 1.77 & 0.56 & 0.22 & 0.24 & 0.76 & 0.25 & 0.08 \\
\hline 20 & 6.51 & 2.89 & 1.19 & 0.61 & 0.21 & 2.10 & 0.88 & 0.14 \\
\hline 27 & 8.32 & 3.67 & 2.59 & 1.55 & 1.07 & 10.12 & 1.23 & 0.28 \\
\hline June, 3 & 6.11 & 10.21 & 10.92 & 4.39 & 0.67 & 10.16 & 8.76 & 0.81 \\
\hline 10 & 3.17 & 18.43 & 26.32 & 16.72 & 0.23 & 12.83 & 19.65 & 12.55 \\
\hline 17 & 1.02 & 5.76 & 35.70 & 28.45 & 0.00 & 2.01 & 22.11 & 10.62 \\
\hline 24 & & 3.11 & 57.93 & 43.92 & & 1.00 & 31.63 & 21.93 \\
\hline July, 1 & & 1.66 & 44.70 & 68.11 & & 0.05 & 14.02 & 39.22 \\
\hline 8 & & & 25.22 & 82.50 & & & 6.00 & 33.43 \\
\hline 15 & & & 11.83 & 61.33 & & & 3.76 & 19.67 \\
\hline 22 & & & & 39.25 & & & & 11.21 \\
\hline 29 & & & & 22.36 & & & & 9.33 \\
\hline $\begin{array}{c}\text { Mean/leaf } \\
\text { /season }\end{array}$ & 2.82 & 4.07 & 17.27 & 30.78 & 0.28 & 3.35 & 9.04 & 13.27 \\
\hline $\begin{array}{l}\text { L.S.D. at } \\
5 \%\end{array}$ & & & & & & & 0.34 & \\
\hline
\end{tabular}

In the second season, results took the same trend as obtained in the first season despite the infestation rates by $A$. gossypii were lower than those recorded in the first season. The seasonal mean numbers of $A$. gossypii found in this season were $(0.28,3.35,9.04$ and 13.27 individuals/leaf) for the four tested planting dates, respectively.

The obtained data in the two studied seasons and their statistical analysis showed clearly that planting of squash seeds in the earliest planting date (March, $15^{\text {th }}$ ) escaped mostly from the infestation of $A$. gossypii.

The present results are in agreement with the findings of Helaly et. al. (1990) who reported that the population density of Aphis craccivora infesting cowpea varied 
significantly according to the time of sowing during summer plantation season. Hassanein (1994) recorded that the population density of $A$. craccivora was significantly affected by the time of sowing. He added that sowing date is an important factor for crop production as well as aphid infestation level. Metwally et. al. (1994) indicated that the highest level of infestation by $A$. gossypii, A. craccivora and Myzus persica occurred in the late summer season than in winter, on common bean and squash. But it contrast with Shalaby (1998) stated that the lowest infestation by A. craccivora and $M$. persicae on common bean occurred during the latest planting date (March, $30^{\text {th }}$ ) while, the earlier planting date (March, $1^{\text {st }}$ and $15^{\text {th }}$ ) harboured the highest number of aphids.

\section{2) Bemisia tabaci nymphs:}

Regarding the data recorded in Table (2), it is obviously clear that, the rates of infestation by B. tabaci nymphs to leaves of squash plants, planted in four different dates took the trend as that occurred in case of aphids, i.e., increasing infestation as the planting date was delayed. In 2009 and 2010 years, the heaviest infestation rates by $B$. tabaci nymphs were significantly, associated with planting on May, $1^{\text {st }}$ (latest planting date), as the seasonal mean counts were 14.19 and 11.36 nymphs/inch ${ }^{2}$, respectively. While the least mean number were 2.78 and 1.42 nymphs/ inch ${ }^{2}$ for 2009 and 2010, respectively in the first date (March, 15 ${ }^{\text {th }}$ ). During 2010 season, infestation rates by $B$. tabaci nymphs to squash were lower than those mentioned in the first season. The mean seasonal of whiteflies recorded in 2010 season were 1.42, 2.61, 5.87 and 11.36 nymphs/inch ${ }^{2}$.

In a similar work on the population fluctuation of B. tabaci, Helaly et. al. (1990) found that numbers of $B$. tabaci immature individuals occurred differently in different summer sowing dates of cowpea crop. El-Sayed et. al. (1991) revealed that the high rate of $B$. tabaci infestation different vegetable host plants were generally oriented to summer plantation, while the early summer plantation manifested lowest rate of infestation. Foda et. al. (1994) detected that the highest population density of B. tabaci adults and nymphs was occurred on pepper during late summer season $\left(3^{\text {rd }}\right.$ week of June), followed by summer ( $3^{\text {rd }}$ week of Feb.). Metwally et. al. (1994) recorded that the late planting dates of squash (June, $15^{\text {th }}$ ) harboured the higher numbers of $B$. tabaci immature stages than the earliest planting dates (Feb., $15^{\text {th }}$ and March, $15^{\text {th }}$ ). Emam et. al. (2006) on sweetpea plants in Egypt, as they reported that the infestation rate of $B$. tabaci increased by delaying planting date. 
Table 2. Mean number of Bemisia tabaci (Genn.) nymphs/inch ${ }^{2}$ on squash plants in different planting dates during the summer plantation seasons of 2009 and 2010.

\begin{tabular}{|c|c|c|c|c|c|c|c|c|}
\hline \multirow{3}{*}{$\begin{array}{l}\text { Sampling } \\
\text { schedule }\end{array}$} & \multicolumn{8}{|c|}{ Planting date } \\
\hline & \multicolumn{4}{|c|}{2009} & \multicolumn{4}{|c|}{2010} \\
\hline & $\begin{array}{c}\text { March, } \\
15^{\text {th }}\end{array}$ & $\begin{array}{c}\text { April, } \\
1^{\text {st }}\end{array}$ & $\begin{array}{c}\text { April, } \\
15^{\text {th }} \\
\end{array}$ & $\begin{array}{c}\text { May, } \\
1^{\text {st }}\end{array}$ & $\begin{array}{c}\text { March, } \\
15^{\text {th }}\end{array}$ & $\begin{array}{c}\text { April, } \\
1^{\text {st }} \\
\end{array}$ & $\begin{array}{c}\text { April, } \\
15^{\text {th }} \\
\end{array}$ & $\begin{array}{c}\text { May, } \\
1^{\text {st }}\end{array}$ \\
\hline April, 1 & 0.00 & - & - & - & 0.00 & - & - & - \\
\hline 8 & 0.52 & - & - & - & 0.19 & - & - & - \\
\hline 15 & 0.96 & 0.04 & - & - & 0.65 & 0.02 & - & - \\
\hline 22 & 1.49 & 0.73 & - & - & 0.71 & 0.56 & - & - \\
\hline 29 & 2.25 & 0.99 & 0.93 & - & 2.00 & 0.84 & 0.67 & - \\
\hline May, 6 & 3.91 & 1.85 & 1.65 & - & 2.85 & 2.12 & 0.99 & - \\
\hline 13 & 4.57 & 2.77 & 2.91 & 1.24 & 1.93 & 1.75 & 1.58 & 0.97 \\
\hline 20 & 5.66 & 3.98 & 4.55 & 6.33 & 2.34 & 3.01 & 3.09 & 3.51 \\
\hline 27 & 4.71 & 8.56 & 9.01 & 6.91 & 2.11 & 6.48 & 6.00 & 4.72 \\
\hline June, 3 & 3.52 & 11.34 & 11.22 & 5.83 & 1.67 & 5.97 & 8.93 & 4.77 \\
\hline 10 & 3.67 & 5.21 & 10.57 & 16.25 & 1.52 & 3.01 & 12.51 & 11.85 \\
\hline 17 & 2.11 & 4.57 & 11.93 & 18.44 & 1.05 & 3.42 & 10.12 & 15.23 \\
\hline 24 & & 3.11 & 6.21 & 29.73 & & 2.76 & 7.05 & 17.11 \\
\hline July, 1 & & 2.84 & 5.98 & 28.32 & & 1.33 & 8.29 & 25.04 \\
\hline 8 & & & 10.46 & 17.55 & & & 5.84 & 20.52 \\
\hline 15 & & & 8.55 & 12.11 & & & 5.32 & 12.32 \\
\hline 22 & & & & 16.00 & & & & 11.85 \\
\hline 29 & & & & 11.51 & & & & 8.46 \\
\hline $\begin{array}{l}\text { Mean/leaf } \\
\text { /season }\end{array}$ & 2.78 & 3.83 & 7.00 & 14.19 & 1.42 & 2.61 & 5.87 & 11.36 \\
\hline $\begin{array}{l}\text { L.S.D. at } \\
5 \%\end{array}$ & \multicolumn{4}{|c|}{0.49} & \multicolumn{4}{|c|}{0.94} \\
\hline
\end{tabular}

\section{3) Thrips tabaci (nymphs and adults):}

Data presented in Table (3) revealed that, the rate of infestation by T. tabaci (nymphs and adults) to squash plants during two successive seasons (2009 and 2010), increased by delaying planting date. As for the first planting date (March, $15^{\text {th }}$ ), squash leaves harboured the lowest seasonal mean count of T. tabaci (30.92 and 22.13 individuals/leaf, respectively). On the contrary, the latest date (May, $1^{\text {st }}$ ) recorded the highest infestation rate (61.51 and 47.80 individuals/leaf, respectively). 
Table 3. Mean number of Thrips tabaci Lind. individuals/leaf on squash plants in different planting dates during the summer plantation seasons of 2009 and 2010.

\begin{tabular}{|c|c|c|c|c|c|c|c|c|}
\hline \multirow{3}{*}{$\begin{array}{l}\text { Sampling } \\
\text { schedule }\end{array}$} & \multicolumn{8}{|c|}{ Planting date } \\
\hline & \multicolumn{4}{|c|}{2009} & \multicolumn{4}{|c|}{2010} \\
\hline & $\begin{array}{c}\text { March, } \\
15^{\text {th }}\end{array}$ & $\begin{array}{c}\text { April, } \\
1^{\text {st }} \\
\end{array}$ & $\begin{array}{l}\text { April, } \\
15^{\text {th }}\end{array}$ & $\begin{array}{c}\text { May, } \\
1^{\text {st }} \\
\end{array}$ & $\begin{array}{c}\text { March, } \\
15^{\text {th }}\end{array}$ & $\begin{array}{c}\text { April, } \\
1^{\text {st }} \\
\end{array}$ & $\begin{array}{c}\text { April, } \\
15^{\text {th }} \\
\end{array}$ & $\begin{array}{c}\text { May, } \\
1^{\text {st }} \\
\end{array}$ \\
\hline April, 1 & 5.11 & - & - & - & 2.06 & - & - & - \\
\hline 8 & 12.71 & - & - & - & 11.00 & - & - & - \\
\hline 15 & 37.35 & 7.85 & - & - & 21.31 & 4.81 & - & - \\
\hline 22 & 49.43 & 19.62 & - & - & 32.51 & 24.33 & - & - \\
\hline 29 & 65.24 & 39.95 & 9.55 & - & 29.67 & 30.00 & 6.45 & - \\
\hline May, 6 & 67.15 & 75.33 & 23.16 & - & 48.73 & 65.71 & 29.11 & - \\
\hline 13 & 40.35 & 82.21 & 55.61 & 12.52 & 41.22 & 72.11 & 42.95 & 9.73 \\
\hline 20 & 32.12 & 96.77 & 87.44 & 31.75 & 37.44 & 77.83 & 83.24 & 30.29 \\
\hline 27 & 31.95 & 72.00 & 99.05 & 69.91 & 28.05 & 46.55 & 77.63 & 51.77 \\
\hline June, 3 & 17.33 & 65.41 & 108.97 & 94.63 & 9.11 & 39.74 & 99.37 & 88.45 \\
\hline 10 & 10.25 & 41.22 & 90.22 & 111.05 & 3.54 & 20.33 & 63.91 & 90.34 \\
\hline 17 & 2.01 & 22.01 & 82.11 & 115.88 & 0.88 & 8.70 & 45.21 & 107.92 \\
\hline 24 & & 18.54 & 59.34 & 90.12 & & 2.94 & 28.45 & 74.56 \\
\hline July, 1 & & 6.91 & 31.15 & 84.56 & & 1.81 & 10.96 & 48.39 \\
\hline 8 & & & 19.42 & 66.31 & & & 6.05 & 37.11 \\
\hline 15 & & & 8.55 & 35.22 & & & 3.21 & 26.47 \\
\hline 22 & & & & 18.47 & & & & 5.94 \\
\hline 29 & & & & 7.83 & & & & 2.63 \\
\hline $\begin{array}{l}\text { Mean/leaf } \\
\text { /season }\end{array}$ & 30.92 & 45.65 & 56.21 & 61.51 & 22.13 & 32.91 & 41.38 & 47.80 \\
\hline $\begin{array}{l}\text { L.S.D. at } \\
5 \%\end{array}$ & \multicolumn{4}{|c|}{0.19} & \multicolumn{4}{|c|}{0.97} \\
\hline
\end{tabular}

Sowing on (April, $1^{\text {st }}$ and $15^{\text {th }}$ ) led to intermediate rate of infestation, as a leaf harboured a mean of (45.65 and 32.91 individuals/leaf) and (56.21 and 41.38 individuals/leaf), respectively. It was obvious that, the degree of infestation of $T$. tabaci was significantly affected by changing the time of sowing. 
In similar work on the population density of T. tabaci Metwally et. al. (1994) recorded that the population density of $T$. tabaci increased in the summer than winter plantation of potato plants. The same authors indicated also that infestation increased by delaying planting date on squash and common bean.

The present results agree with those of Shetgar et. al. (1994), on groundnut, Wnuk and Wiech (1996), on pea plants, Salman and Abou-Elhagag (2001) on faba bean, Sahu et. al. (2005) on linseed crop and Emam et. al. (2006) on sweetpea plants, as all reported that there was significantly less thrips population on plants sown in the earliest planting date, while those sown in the latest planting date had the highest thrips population. But it contrast with Efil (2003) who stated that the late sowing date of cotton resulted in a very low $T$. tabaci population.

\section{4) Effect of planting dates on yield:}

In both studied seasons (2009 and 2010), as shown in Table (4), data indicated that the squash yield increased by early sowing date. The highest seasonal mean weight of squash fruits obtained from squash plants planted in the first planting date being 9.39 and $10.89 \mathrm{~kg} /$ plot with the highest number of fruits 108.25 and 116.00 fruits/plot in the two seasons, respectively.

On the contrary, squash plants planted in the latest planting date produced the lowest weight of squash fruits of 3.08 and $4.25 \mathrm{~kg} / \mathrm{plot}$ with the lowest number of fruits 39.52 and 50.73 fruits/plot in the two seasons, respectively.

It could be concluded that the earliest planting date (March, $15^{\text {th }}$ ) gave higher yield than the other three tested planting dates and this may be related to the lowest numbers of pests were present and convenience of dominated climatic factors during this planting date for growth of squash plants.

The present results agree with those of Shetgar et. al. (1994) and Bairwa et. al. (2005), they stated that earliest planting date produced significantly highest weight of yield. 
Table 4. Average yield per plot of squash in different planting dates during the summer plantation seasons of 2009 and 2010.

\begin{tabular}{|c|c|c|c|c|c|c|}
\hline \multirow[b]{2}{*}{ Planting date } & \multicolumn{2}{|c|}{2009} & \multicolumn{2}{|c|}{2010} & \multicolumn{2}{|c|}{ General mean } \\
\hline & $\begin{array}{c}\text { Yield } \\
\text { (kg/plot) }\end{array}$ & $\begin{array}{c}\text { No. of } \\
\text { fruits/plot }\end{array}$ & $\begin{array}{c}\text { Yield } \\
\text { (kg/plot) }\end{array}$ & $\begin{array}{c}\text { No. of } \\
\text { fruits/plot }\end{array}$ & $\begin{array}{c}\text { Yield } \\
\text { (kg/plot) }\end{array}$ & $\begin{array}{c}\text { No. of } \\
\text { fruits/plot }\end{array}$ \\
\hline March, $15^{\text {th }}$ & 9.39 & 108.25 & 10.89 & 116.00 & 10.14 & 112.13 \\
\hline April, $1^{\text {st }}$ & 7.11 & 91.35 & 8.75 & 100.50 & 7.93 & 95.93 \\
\hline April, $15^{\text {th }}$ & 5.18 & 72.14 & 7.59 & 98.02 & 6.39 & 85.08 \\
\hline May, $1^{\text {st }}$ & 3.08 & 39.52 & 4.25 & 50.73 & 3.67 & 45.13 \\
\hline L.S.D. at $5 \%$ & 0.32 & - & 0.21 & - & 0.31 & - \\
\hline
\end{tabular}

\section{REFERENCES}

1. Anuj-Bhatnagar 2007. Incidence and succession of thrips, leafhoppers and whitefly in combination of planting dates and potato varieties. Ann of Plant Protection Sci., 15 (1): 101-105.

2. Bairwa, D. K., P. M. Kanwat and K. C. Kumawat. 2005. Effect of dates of sowing on the incidence of jassids, whiteflies and shoot fruit borer of the okra. Ann. Agric. Res., 26 (1): 110-112.

3. Booij, K. 2003. Dynamics of Thrips tabaci in diversified agro-ecosystems, a modelling approach. Bull. OILB/SROP, 26 (4): 19-24.

4. Efil, L. 2003. The effect of different sowing dates to populations development of Thrips tabaci Lind. (Thysanoptera : Thripidae) in Hurran conditions. Ziraat Fakultesi Dergisi Ataturk Universities, 34 (1): 41-43.

5. El-Sayed, A. M., F. F. Shalaby, A. A. Abdel Gawad. 1991. Ecological studies on Bemisia tabaci (Gennadius) (Hemiptera : Homoptera : Alyrodidae) infesting different host planting. I. Fluctuation and population density of Bemisia tabaci on different host plants. Egypt. J. Agric. Res., 69 (1): 193-207.

6. Emam, A. Z., M. F. A. H. Hegab and M. A. M. Tantawy. 2006. Effect of planting space and date on the population densities of certain insect pests infesting sweet pea plants at Qalyoubia Governorate. Annl. Agric. Sci. Moshtohor, 44 (1): 299308.

7. Fisher, R. A. 1950. Statistical methods for research workers. II. Rev. Ed. Oliver and Boyed, London.

8. Foda, M. E., M. Salem and B. M. Attia. 1994. Population dynamics of whitefly, Bemisia tabaci (Genn.) in certain vegetable crops in Egypt. J. Agric. Sci. Mansoura Univ., 19 (3): 1233-1243. 
9. Hassanein, S. S. M. 1994. Effect of some crop management practices on population of certain insects infesting broad bean plants at Khattara region, Egypt. Zagazig J. Agric. Res., 21 (6): 1807-1816.

10. Helaly, M. M., S. S. M. Hassanein and S. I. Yousif-Khalil. 1990. Effect of sowing dates on cowpea infestation with certain pests at Zagazig, Egypt. Egypt. J. Appl. Sci., 5 (2): 64-76.

11. Jarosik, V., M. Kolias, L. Lopchin, J. Rochat and A. F. C. Dixon. 1997. Seasonal trends in the rate of population increase of Frankliniella occidentalis (Thysanoptera : Thripidae) on cucumber. Bull. Entomol. Res., 87 (5): 487-495.

12. Metwally, E. M., S. S. M. Hassanein and A. F. E. Afsa. 1994. Effect of planting date on the population abundance of certain leaf pests infesting some vegetable crops at Gemmeza region, Egypt. Egypt J. Agric. Res., 72 (4): 977-988.

13. Rizk, G. N. and K. G. Ahmed. 1981. Population dynamics of some insect pests attacking squash plant, Cucurbita pepo L. in Iraq. Res. Bull., Fac. Agric., Ain Shams Univ., 1653: 8-13.

14. Sahu, K. R., Y. K. Yadu and M. K. Chandrakar. 2005. Impact of different dates of sowing on the incidence of linseed thrips, Caliothrips indicus (Bagnall) on linseed crop. Environ. and Ecol., 23 (special 2): 353-355.

15. Salman, A. M. A. and G. H. Abou-Elhagag. 2001. Effect of sowing dates of faba bean on Thrips tabaci Lind. population in upper Egypt. Assuit J. Agric. Sci., 32 (4): 39-47.

16. Shalaby, S. H. 1998. Studies on the principle insect pests attacking common bean in the field. M. Sc. Thesis, Fac. Agric., Moshtohor, Zagazig Univ., 93 pp.

17. Shetgar, S. S., G. G. Bilapate and G. M. Londhe. 1994. Effect of sowing dates on pests incidence and yield losses due to foliage pests on ground nut. Indian J. Entomol., 56 (4): 441-443.

18. Wnuk, A. and K. Wiech. 1996. The effect of spacing, date of sowing and intercropping on the occurrence of pea pests. Roczniki, Nauk. Rolniczych, Seria E, Ochrona Roslin, 25 (1/2): 9-14. 


\title{
تأثير مواعيد الزراعة علي الإصابة ببعض الآفات

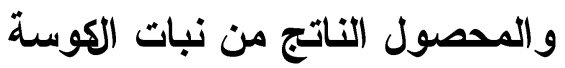

\author{
منى عبد الحميا محمد \\ معرة بحوث وقاية النباتات- مركز البحوث الزراعية - الكقي- جيزة- 12618 مصر
}

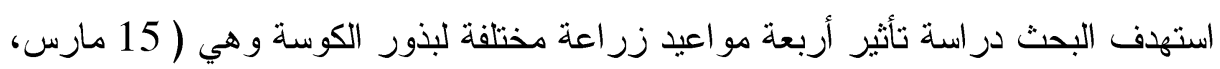

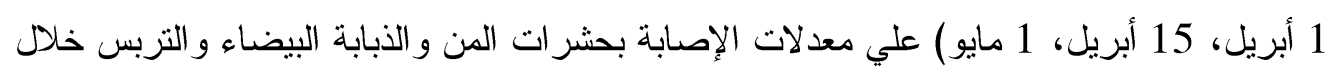

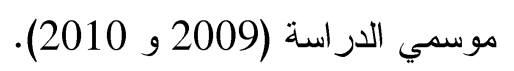

أوضحت النتائج أن تأخير ميعاد الزراعة كان له نأثير معنوي في زيادة الإصابة بحشرات

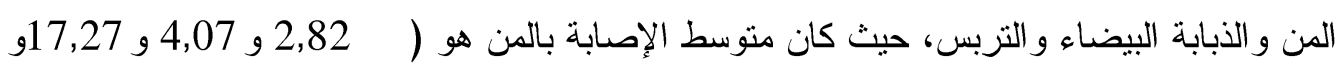

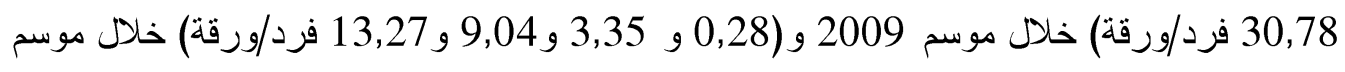

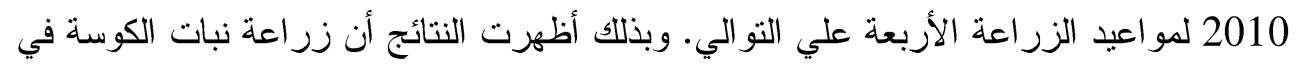

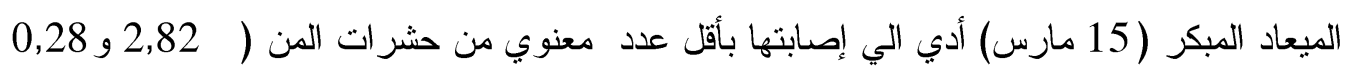

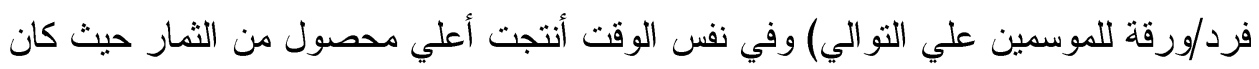

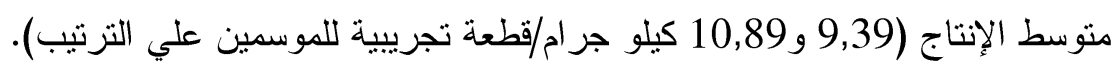

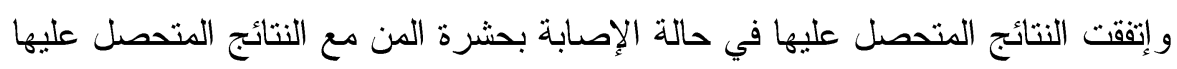

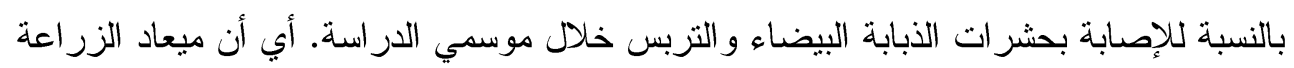

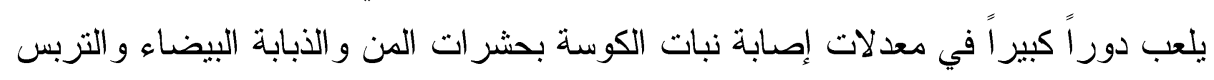

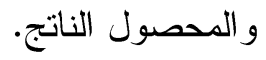

